日消外会誌 $41 （ 2 ） ： 269 \sim 274 ， 2008$ 年

臨床経験

薬剤溶出性冠動脈ステント留置後に発見された胃癌症例の臨床経験

東京大学医学部附属病院胃 - 食道外科, 同 循環器内科*

\begin{tabular}{|c|c|c|c|c|c|}
\hline 畑尾 & 和田 & 郁雄 & 山口 & 浩和 & 野村 \\
\hline 和彦 & 吉川 & 朱実 & 森 & 和彦 & 藤田 \\
\hline 敏宏* & 上西 & 紀夫 & & & \\
\hline
\end{tabular}

近年，虚血性心疾患に対して行われる冠動脈ステント治療において免疫抑制剤や抗癌剤を表 面に塗布し徐放化させる薬剤溶出性ステント（drug-eluting coronary stent；以下，DES）が多 用されている. DES は従来の金属露出型ステントより再狭窄率が低いという重要な長所を持つ が，留置後 1 か月以降に遅発性血栓症が起こるリスクを有しており，使用患者はアスピリンの 終生投与およびチクロピジンの最低 3 か月以上の投与が必須とされている. DES 留置後に消化 器癌が指摘されると, 出血リスクを避けるために周術期に抗血小板薬の休止が必要となるが, ヘパリン点滴持続静脈投与への変更などによる抗凝固療法による代替の安全性に関するエビデ ンスはそしい.我々は DES 留置後に胃癌が発見された 3 症例を経験したため文献的考察を含め て検討し，指針を考案した。

\section{はじめに}

近年, 虚血性心疾患に対して行われる冠動脈ス テント治療において従来の金属露出型ステント (bare metal stent ; 以下, BMS)に代わって, 免疫 抑制剂や抗癌剂を表面に塗布し徐放化させる薬剤 溶出性ステント (drug-eluting coronary stent ; 以 下，DES）が一般化してきた。 日本では免疫抑制

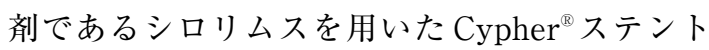
が多用されている。シロリムスは元来マクロライ ド系抗生物質であるが，強力な血管平滑筋増殖抑 制作用が着目され DES に採用された。 DESはそ の特性から従来のステントより再狭窄率が低いと いう重要な長所を持つが, 留置後 1 か月以降に遅 発性血栓症が起こるリスクも有しており, 使用患 者は長期間に及ぶ抗血小板薬服用が必須である. DES 使用ガイドライン ${ }^{1)}$ においてアスピリンの終 生投与およびチクロピジンの最低 3 か月以上の投 与が推奨されている.

DES 留置後に消化器癌が指摘された場合, 手術

$<2007$ 年 7 月 25 日受理 $>$ 別刷請求先 : 烟尾 史彦 T113-8655 文京区本郷 7-3-1 東京大学医学部附 属病院胃・食道外科
などを行うにあたって抗血小板薬の休止および抗 凝固療法による代替が必要となるが, DES は発売 後歴史が浅く抗血小板薬の休止の安全性に関する エビデンスが十分ではない，そのため，現状では 施設ごとに独自の判断で周術期に抗血小板薬中止 のみから抗凝固療法による代替が行われる場合な ど対応に幅がある。実際に DES 留置 29 か月後に 手術 10 日前から抗血小板薬服用を中止して腹部 手術を施行したところ, 手術直後に遅発性血栓症 により急性心筋梗塞を発症した症例が報告されて いる2).

\section{目的}

DES 留置後に胃癌が発見された 3 症例を通し て, 現状と問題点について検討する.

症例 $1: 61$ 歳, 男性

現病歴：05 年 4 月，急性心筋梗塞を発症した. 当初は前医にて保存的に加療した。同年 9 月，狭 心症症状が残り右冠動脈領域に viability がある ということで経皮的冠動脈インターベンション (percutaneous coronary intervention ; 以下, PCI）を施行された.このとき, 右冠動脈＃1，3 にDESを留置した. その後, アスピリン $100 \mathrm{mg}$, 
チクロピジン $200 \mathrm{mg} / \mathrm{day}$ を内服していた

06 年 3 月より下血があり上部消化管内視鏡検 査を行い, 胃癌を指摘された. 5 月上旬, 前医指示 によりチクロピジンを休薬され 5 月中旬に当科紹 介受診となった。

紹介後の経過 : 精查にて cT2, N0, H0, P0, CYX, M0 と診断された. 進行癌にて当科の方針に 従い腹腔鏡手術の適応外と判断し, 開腹手術の方 針となった. 6 月上旬に入院し, 入院当日からアス ピリンも休薬した. 同時に入院当日から手術 6 時 間前までへパリン 10,000 単位/day を点滴持続静 脈投与した. 入院 9 日目に手術（幽門側胃切除, D2, 胆囊摘出, Roux en Y 再建) を施行した。 出

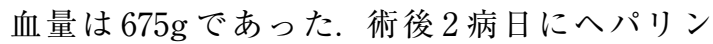
10,000 単位/day の点滴持続静脈投与を再開した. 術後 4 病日にアスピリン $100 \mathrm{mg}$, チクロピジン $200 \mathrm{mg}$ /day を再開した。同時にヘパリンを 5,000 単位/dayに減量した. 術後 9 病日にヘパリンを中 止した. 術後 16 病日, 合併症はみられず退院され た. 以降, 07 年 4 月現在までアスピリン, チクロ ピジンは服用を継続しており, 胃癌の再発はみら れていない.

病理組織学的検查所見: Type 3, $2.2 \times 1.2 \mathrm{~cm}$ in size, Locus $\mathrm{M} /$ Ant-Less, por2, depth ss, sci,

INF $\gamma$, ly0, v1, pm-, dm-, n (0/45).

最終診断: fT2N0H0P0CY0M0 Stage IB.

本症例の周術期の抗凝固治療および APTT 值 の経過を示した (Fig.1).

症例 $2: 67$ 歳, 男性

現病歴：00 年, 3 枝病変に対して BMS ステン 卜を留置された。 05 年 3 月に PCI 施行し, 左回旋 枝に狭窄を認めDES が留置された（前医）。同年 3 月下旬より，心窩部痛を訴えていた４月下旬に 上部消化管内視鏡検査が行われ， $\mathrm{M}$ 領域が主座の 広範な 0-IIa + IIc 病変が指摘されたがアスピリ ンを服用していたため観察のみとなった。 6 月上 旬にアスピリンを休薬して内視鏡が再検され，組 織生検が行われ悪性所見を指摘され当院へ紹介と なった。

紹介後の経過：6月中旬当科を初診された. 7 月上旬に検査入院を行い, 循環器内科によって術
前に心臓カテーテル検査を行った．回旋枝\#15 に $99 \%$ 狭窄, 右冠動脈＃4AVに $75 \%$ 狭窄を認め たが，末梢病変にて手術に大きな支障はないと判 断された. 胃癌は cT1 $(\mathrm{SM}), \mathrm{N} 0, \mathrm{H} 0, \mathrm{P} 0, \mathrm{CYX}$, $\mathrm{M} 0$ と診断された。疾患を有するため腹腔鏡手 術の適応外と判断し開腹手術を行う方針となっ た. 7 月に入院となった.チクロピジンは前医では 処方されていなかった。 アスピリンを休薬し，同 時に入院当日から手術 6 時間前までヘパリン 10,000 単位/day 点滴持続静脈投与した. 入院 9 日目に手術 (胃全摘術, $\mathrm{D} 1+\beta$, 空腸間置)を行っ た. 出血量は $330 \mathrm{~g}$ であった. 術後 3 病日にアスピ リン $100 \mathrm{mg}$, チクロピジン $200 \mathrm{mg} /$ day を再開し た. 8 月上旬, 合併症もなく無事退院された。 07 年 4 月現在までアスピリン, チクロピジンの服用 は継続され, 胃癌の再発はみられていない.

病理組織学的検查所見 : 0 - IIa + IIc + IIb, $5.5 \times$ $5.0 \mathrm{~cm}$, Locus $\mathrm{M} /$ Less, tub1>tub2, por2, depth sm, INF $\beta$, ly0, v0, pm-, dm-, n $(0 / 27)$

最終診断 : fT1N0H0P0CY0M0 Stage IA.

本症例の周術期の抗凝固治療および APTT 值 の経過を示した（Fig. 2).

症例 $3: 74$ 歳, 女性

現病歴 : 84 年, 完全房室ブロックを認め, ペー スメーカーが留置された. 92 年, 05 年にペース メーカー交換が行われた. 06 年 4 月，うっ血性心 不全により当院循環器内科入入院となった. PCI を施行し，\#1，2，6，7，12，13 にDESが留置さ れた. 留置後からアスピリン, チクロピジンの投 薬を開始した。その後, 貧血が遷延し, 消化管内 視鏡検査を施行したところ胃前庭部の陥凹性病変 および幽門の軽度狭窄が指摘され，進行胃癌が疑 われたが抗血小板薬服用中にて観察のみにとど め, 当科へ紹介となった。

紹介後の経過 : 6 月中旬に家族, 本人, 循環器内 科医と面談した. 胃癌を積極的に疑う所見のため, 抗血小板療法をへパリン点滴持続静脈投与に一時 変更したうえで，内視鏡による組織学的検査を锥 めるも「服薬を中断することで血栓症のリスクが 高くなることが怖いので, 3 か月の服薬は遵守し たい」ということで同意が得られず，循環器内科 
Fig. 1 Anticoagulation treatment during the perioperative period in Case 1 .

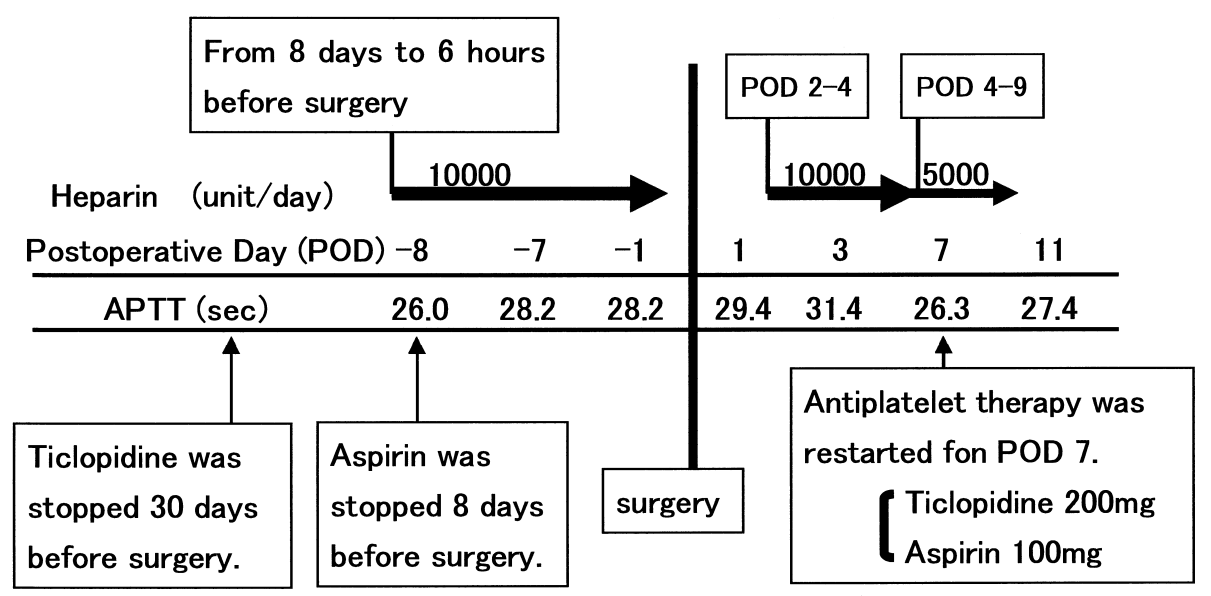

Fig. 2 Anticoagulation treatment during the perioperative period in Case 2 .

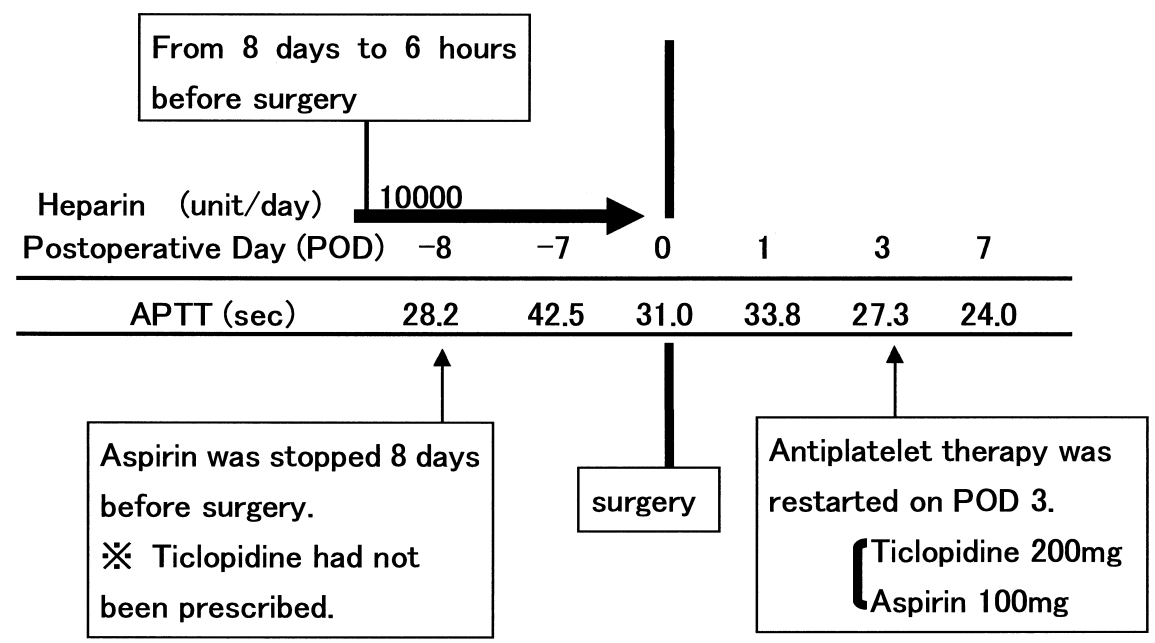

を退院された. 8 月中旬, DES の留置から 3 か月 が過ぎ，患者の同意が得られたため当科へ検査入 院となった．抗血小板療法をへパリン点滴持続静 脈投与に一時変更し, 内視鏡を再検し組織学的検 査にて分化型腺癌の診断となり, cT2N0M0 H0 Stage IBにて手術を予定していた. しかし, 8 月下 旬に幽門の軽度狭窄により誤嚥性肺炎を発症し, その後敗血症となり, さらに心不全となったため 循環器内科へ転科された. 9 月中旬, 全身状態はや や改善したが，心不全は持続した状態であった。 この時点で「胃癌に対して根治を目指すなら切除 手術が必要であるが, 全身状態が良くないので手
術侵襲によって致命的になる危険性がある」とい うことを説明し，もともと本人とご主人が手術に 消極的であった経緯もふまえ，手術は行わず緩和 治療を中心としていく方針となった。この際にア スピリン, チクロピジンは再開した. 9 月下旬, 少 量ながら食事も摂取し, 全身状態が安定したため 一時退院を試みた。 その後, 心不全の増悪などに より循環器内科へ再入院となった。この際に幽門 の通過障害に対する症状緩和を目的に放射線治療 を行った，再度食事摂取も少量なされていた，12 月中旬に緩和ケア目的に近医へ転院された。 


\section{考察}

PCI の最大の課題であった新生内膜の増殖によ る再狭窄抑制を目的に開発された DES は, 海外で の大規模臨床試験において臨床的有用性が示さ れ3)，本邦においても急速に広まり，PCIにおける 中心的な治療手段となった ${ }^{4) 51}$. 冠動脈ステントの 合併症として最も重大なのはステント血栓症であ り, 発症時は $2 / 3$ 以上が心筋梗塞を発症し, その 死亡率は約 $50 \%$ とされる . ステント血栓症の予 防として 90 年代後半にまだ BMSのみが行われ ていた時期に, 種々の臨床試験によりアスピリン と第一世代チエノピリジンであるチクロピジンの 併用投与が最も有益であることが報告された 来の BMS では，ステント表面を内皮が覆い始め る 2 週間を過ぎると血管内異物に対する反応がな くなり，血栓症のリスクは低下するためチクロピ ジンの投与は留置後 1 か月程度で終了しても問題 にならないとされている5).また, 海外の報告では BMS 留置後 2〜6 週間以内の手術 (非心臓) は血栓 症の発症リスクを増加させるため, 予定手術の場 合は 4 週間以上経ってから手術を行うことを推奨 している7).

一方, DES は内膜の生成が遅延するため, 血栓 形成のリスクが長期間にわたって持続する可能性 が指摘されてきた6).その結果, BMS ではそれほど 問題とならなかった留置後 1 か月以降に遅発性血 栓症が起きうること孚が考慮され, 抗血小板薬の長 期投与の必要性が指摘されてきた。 国内において

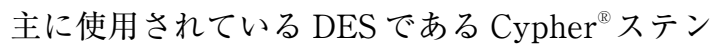
卜留置後の血栓症に関しては, 集計が発表帛されて おり，発生頻度は $0.3 \%$ 程度で, DES 留置から 30 日以内が $77 \%$ であり, 血栓症発生の原因は抗血小 板薬に関連するものが $32 \%$ であったとされてい る.これらの結果がチクロピジンを DES 留置後に 最低 3 か月間は投与することを推奨する根拠と なっている.

しかし最近になって，チクロピジンの服用を 1 年以上続けることを推奨する報告が増えてきた. ステント留置患者における非心臓手術後の心血管 イベントの発生リスクを BMS と DES で比較し

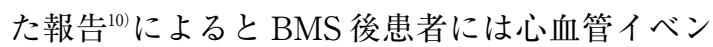

トは発生しなかったが, DES 後患者 138 名のうち 3 名にステント血栓症が発症し, うち 2 名はステ ント留置後それぞれ 264 日，367日後に手術を 行った症例であった. DES 群に重症例が多いと推 測されるため単純には評価できないが, 留置から 1 年以上過ぎていてもリスクがあるという結果は 重要であり, DES 留置後の手術に際する抗血小板 薬の休止には注意が必要であると考えられる.

また，米国の関連主要 5 学会が 07 年に合同で 行った報告では, DES 留置後はステント血栓症予 防のために抗血小板薬を 1 年以上は続ける必要が あることが提言された ${ }^{11)}$ ，ステント内血栓症によ る死亡率は 20 から $45 \%$ とされ, DES 留置後に于 エノピリジン系薬片を早期に中断することの危険 性を説いている。また，手術に関連したことは以 下のように提言されている.

・ 12 か月以内に手術を控えている場合 DES を避 けBMSにて一時的に血管形成を行うべきであ る. また，予定手術は DES 留置後なら 12 か月， BMS 留置後なら 1 か月は待機するべきである.

・手術治療をする際, 出血を避けるためにチエノ ピリジン系薬剤を中断することによるステント血 栓症のリスクを十分に考慮する.

・DES 留置患者がチエノピリジン系薬剂を中断 せざるを得ない場合は，可能なかぎりアスピリン は継続し，チエノピリジン系薬剂は術後可能な限 り早く再開するべきである.

この提言にもある通り，手術予定の患者に冠動 脈狭窄が発見された場合は，ステント留置の適応 については病状から心血管イベントリスクを十分 に考虑し，検討する必要がある，当院では広範囲 な灌流域を持つ責任血管の $90 \%$ 以上の高度狭窄 症例や不安定狭心症の場合には, 周術期に心血管 イベントを引き起こすリスクが高いと憂慮される ため術前にステント留置の適応としているが，こ の場合 DES の留置は避け，必要最小限の範囲に BMS を留置し, 術後に必要に応じて DES 留置を 行うことを原則としている. ただし，BMSであっ ても留置後 1 か月は抗血小板薬を中断することは 亜急性ステント血栓症のリスクが高まるため, 症 例の消化器疾患の緊急性などによって十分に適応 
を検討する必要があると考えている.

また，前述の 5 学会の合同提言ではやむを得ず 手術を行う場合の抗凝固治療などの具体的な代替 案は示されていない。医学中央雑誌で「薬剤溶出 性ステント」「手術」をキーワードに 2003 年〜2007 年の期間で検索したところ, DES 留置後手術が必 要になった場合の周術期の抗血小板治療の代替治 療に関する国内でのアンケート調査 ${ }^{12)}$ の一報告が なされていた，それによると，1）へパリンを使用 したうえでアスピリン，チクロピジンを休止（8 施設)，2）2剂とも直前まで服用(2 施設)，3）千 クロピジンのみ休薬しヘパリンを併用(11 施設), 4） 2 剂とも休止し, ヘパリンも不使用 (7 施設), というように施設ごとに異なる方針であった.

今回, 我々は DES 留置後に胃癌が発見された 2 例についてはへパリン点滴持続静脈投与による代 替を用いて無事に手術を行うことができたが, 1 例については, 全身状態の問題もあって結果的に 根治的治療を行うことができないという残念な結 果になった。当院では Cancer Board を開催して 各科に横断的な課題を含む症例について積極的に 討論している。今回報告した 3 症例の経験を踏ま え, 消化器外科, 消化器内科および循環器内科で この問題について討論を重ね, DES 留置後に手術 が必要となった場合にステント血栓症予防の観点 から推奨される周術期の抗凝固療法の基本方針を 以下のごとく設定した.

・手術 1 週間前にアスピリンおよびチクロピジン を休止し，ヘパリン点滴持続静脈投与を 10,000 15,000 単位/day から開始し APTT を前值 2 倍程 度を上限目標に，手術時の出血リスクとの兼ね合 いで投与量を調整する.

・ヘパリン点滴持続静脈投与は手術 3〜 6 時間前 に休止し, 術後は出血リスクが最小化した時点(原 則として手術 24 時間後)からへパリン点滴持続静 脈投与を再開する.

・内服（抗血小板薬）を再開してから 3 日後にへ パリン点滴持続静脈投与を終了する.

DES 留置後の外科手術の周術期に伴う抗血小 板薬の中断, 抗凝固治療による代替に関する安全 性は，国内外を含めエビデンスがまだ十分とはい
えない．今後は症例を蓄積すると同時に prospective study を行って検討し, 根拠に基づいた周術 期における代替抗凝固療法の標準化がなされるこ とが必要である。

\section{文献}

1）上妻 謙, 田辺健吾, 門田一繁: シロリムス溶出 性ステント使用に際して推奖される抗血小板療 法 カテーテル治療. 日心血管カテーテル治会誌 5 (Suppl 2) : 46-48, 2005

2) de Souza DG, Baum VC, Ballert NM : Late thrombosis of a drug-eluting stent presenting in the perioperative period. Anesthesiology 106 : 1057-1059, 2007

3) Windecker S, Remondino A, Eberli FR et al : Sirolumus-eluting and paclitaxel-eluting stents for coronary revascularization. N Engl J Med 353 : 653-662, 2005

4）一色高明：INTERFACE 臨床 薬郕溶出性又 テント（DES）に対する抗血小板療法をどうする か? Int Rev Thromb 1:43-47,2006

5）宇治郷論, 寺川宏樹, 上田健太郎ほか：薬郕溶出 性ステント留置後にチクロピジンの内服を中止 にせざるを得なかった症例についての検討. 広島 医 59:693-699, 2006

6) Angiolillo DJ, Morikawa K, Costa MA et al : Clinical science how to develop antiplatelet treatment for drug eluting stents? Int Rev Thromb 1: 4857,2006

7) Wilson SH, Fasseas P, Orford JL et al : Clinical outcome of patients undergoing non-cardiac surgery in two months following coronary stenting. J Am Coll Cardiol 42 : 23-40, 2003

8) McFadden EP, Stabile E, Regar E et al : Late thrombosis in drug-eluting coronary stents after discontinuation of antiplatelet therapy. Lancet $364: 1519-1521,2004$

9）ジョンソン・エンド・ジョンソン株式会社： $\mathrm{Cypher}^{\circledR}$ ステントに関する打知らせ。 24,2006 http://www.cordiscardiology.jp/library/files/ catalogue/info/cypher_info_24.pdf 2006-06-15

10) Kim HL, Park KW, Kwak JJ et al : Stent-related cardiac events after non-cardiac surgery : drugeluting stent vs. bare metal stent. Int J Cardiol : (In press, available online 8 March 2007)

11) Grines CL, Bonow RO, Casey DE et al : Prevention of premature discontinuation of dual antiplatelet therapy in patients with coronary artery stents : a science advisory from the American heart association, American college of surgeons, and American dental association, with representation from the American college of physicians. Circulation $115: 813-818,2007$

12）本田英彦, 目黒泰一郎：DES 留置後に主要な手術 
の必要が生じたとき. Coronary Intervent $1: 57$,

2005

\title{
Cases of Gastric Cancer Discovered after Drug-Eluting Coronary Stent Implantation
}

\author{
Fumihiko Hatao, Ikuo Wada, Hirokazu Yamaguchi, Sachiyo Nomura, \\ Kazuhiko Yamada, Akemi Yoshikawa, Kazuhiko Mori, Hideo Fujita*, \\ Toshihiro Morita* and Michio Kaminishi \\ Department of Gastrointestinal Surgery and Department of Cardiovascular Medicine*, \\ Graduate School of Medicine, The University of Tokyo
}

Drug-eluting coronary stents (DES) incorporating an eluting antiproliferative agent are commonly used to treat coronary heart disease. While DES reduce the rate of coronary artery restenosis, they have a higher incidence of late thrombosis compared to bare metal stents. Patients are maintained on dual antiplatelet therapy with aspirin and thienopyridine. If the patient suffers from digestive cancer after DES implantation, antiplatelet therapy is temporarily halted, and replaced by heparin administration to avoid perioperative bleeding risk. No evidence exists, to our knowledge is that this drug substitution is safe. We report two successfully treated and one unsuccessfully treated case of gastric cancer involving DES implantation. We review the literature and propose anticoagulation treatment guidelines for DES patients undergoing surgery.

Key words : drug-eluting coronary stent, antiplatelet therapy, perioperative control

[Jpn J Gastroenterol Surg $41: 269-274,2008$ ]

Reprint requests : Fumihiko Hatao Department of Gastrointestinal Surgery, Graduate School of Medicine, The University of Tokyo 7-3-1 Hongo, Bunkyou-Ku, 113-8655 JAPAN

Accepted : July 25, 2007 